\title{
The Integration of Periodic Markets in Mayan Guatemala: A Gravity Approach ${ }^{\dagger}$
}

\author{
E. Anthon Eff* \\ Middle Tennessee State University, Murfreesboro, TN \\ Christa D. Jensen* \\ West Virginia University, Morgantown, WV
}

\begin{abstract}
Mayan towns in the Guatemalan highlands hold markets on specific days of the week. A market is attended by local townspeople, by peasants residing in the town's hinterland, and by vendors bringing wares from other towns. A market functions to bring in goods from other ecological zones, to bring in goods from higher order centers, and to sell surpluses of locally produced goods. To understand how these markets are integrated, we develop a gravity model, examining the flow of vendors from 85 towns of residence to 15 market towns. In our model, the flow of vendors from one town to another is a function not only of physical distance, but of ecological complementarities, of linguistic differences, of road access, and of demographic endowments.
\end{abstract}

Key words: Periodic Markets, Gravity, Ecology, Culture, Gender

JEL category: I20

$\dagger$

A version of this paper was presented at the Southern Regional Science Association meetings, Charleston, South Carolina, March 31, 2007.

*E. Anthon Eff, Associate Professor, Department of Economics and Finance, Box X050, Middle Tennessee State University, Murfreesboro, TN 37132, phone: 615-898-2387, eaeff@mtsu.edu

*Christa D. Jensen, Graduate Research Fellow, Regional Research Institute, Department of Economics, West Virginia University, 511 North High Street, PO Box 6825, Morgantown, WV 26506. Phone: (304) 293-8543; Fax: (304) 293-6699; Christa.Jensen@mail.wvu.edu 


\section{Introduction}

Periodic markets meet at specified locations on specified days. The periodicity of the market can range from several times a week, to once a month, or meet at even longer intervals. Periodicity allows small producers, who can devote only a portion of their time to selling, to sell directly to consumers, without a middleman. Periodic markets can range from urban neighborhood markets, common in the Middle East, to small town markets, such as those in Guatemala's Mayan highlands, attended by peasants who live within the hinterlands. These markets often originate hundreds of years in the past, evolving spontaneously to integrate the local area into a much larger supply region. The integration is accomplished by facilitating exchange between local residents and many small-scale vendors. While the primary function of these markets is to deliver consumer goods to the local population, they can also perform the function of gathering up local surpluses for sale elsewhere.

Spatial integration in a market system involves linking complementary areas. Rural, food-producing areas are linked to urban areas producing manufactured goods; areas plentifully endowed with a particular resource are linked to areas with different endowments. In a landscape such as highland Guatemala, the most salient complementarities would be those spanning ecological zones, from the warm lands of the coast to the colder plateau, and spanning the central place hierarchy, from the rural peasant household to the capital city with its global connections. More modest complementarities are found within even the smallest rural market area, linking, for example, the peasant with an abundance of avocadoes to another with a surplus of tomatoes.

The municipalities of highland Guatemala originated as Spanish administrative centers. Each municipality is similar to a county in the U.S. political system, with a principal town and a rural hinterland containing isolated homes and hamlets (aldeas), some of which may be large. The population of the principal towns contains many Ladinos (Spanish speakers), while the population of the countryside is almost entirely Indian. The purpose of these towns is not so much to service the rural hinterland, as to administer them (Smith 1975: 103). Activity in periodic markets consists primarily of the selling of rural products, with relatively little selling of imported or domestically produced manufactures to rural residents. In fact, only the Ladino population has historically consumed imported goods; the Indian peasants produce most of what they consume, with the exception of goods such as iron tools (Smith 1975: 111-112). 
Guatemalan marketing arrangements are typical of a "solar" pattern found throughout Latin America, in which each lowest order center is tied to a regional higher order center, but there are few links among the lowest order centers or among the regional higher order centers (Smith 1975: 99). Instead, the regional higher order centers link directly to the capital, a primate city, in a "dendritic" pattern that is especially efficient for marshalling commodities from the countryside for export. In the highlands, coffee is the exported commodity and commercial establishments (not periodic markets) function to gather and ship the crop. The role of periodic markets is to bring rural products for local consumption to the centers occupied by commercial establishments (Smith 1975: 100, 114).

While much of the produce of a periodic market is destined for town dwellers, some of it is sold to other rural Indians, and some of these goods (such as traditional textiles) are never purchased by Ladinos. Nevertheless, investigators have found that there is little specialization and exchange across the major Indian markets (Smith 1975: 105, 114). Recent survey work in markets around Lake Atitlan (Murakami 1997) has shown, however, that there are large numbers of vendors who travel to markets outside their home municipality, indicating that Indian markets may be better integrated than previously thought. To date, no systematic analysis has been done to uncover the patterns shaping vendor movements. Do these movements integrate different ecological zones? Are there regional specializations not based on ecology? Are vendors traveling in search of higher prices? Do language barriers funnel vendors toward specific markets? The answers to these questions are not yet known.

The fact that Indian consumption standards are distinct from those of the Ladino population (whose standards are similar to those found in Anglo-America and Western Europe) gives the markets featuring Indian goods a certain exotic appeal. Since at least the 1940s tourists have found shopping for Indian goods, particularly textiles, to be a satisfying experience. Recent ethnographic work has described participants in Indian markets frequented by tourists (Little 2004), or in markets not much visited by tourists (Mendoza Alvarado 1999), but little has been done to compare systematically tourist markets with traditional markets. When a market achieves the status of becoming a major tourist destination, how does that affect the movement of vendors to that market? 


\section{Guatemalan Markets}

\section{Tourist versus Traditional Markets}

In Guatemala, there are now two types of periodic markets, subsistence markets and típica markets. Items sold in subsistence markets are first and foremost food items, but also include cooking utensils, blankets, and clothing for individuals. Típica markets appeared around the 1940's when tourists first started to visit Guatemala in large numbers in order to see the beautiful landscapes and the indigenous peoples. These markets developed when some of the Mayan subsistence vendors turned their interests to the tourists they were observing all around them. Eventually, as more and more Mayan vendors began to sell handicrafts instead of subsistence items, típica markets began to flourish in certain areas of Guatemala.

Most of the goods sold in típica markets are Mayan Indian handicrafts such as textiles, hand-woven clothing, baskets, pottery, and small hand-crafted figurines sold as mementos. These handicrafts are bought in Guatemala by tourists and dealers alike and show up in homes, boutiques, and shops all around the world, demonstrating the extensive reach of spatial integration even outside of the country (Little 2004). In essence these markets are also periodic; however, their periodicity depends upon the tourist schedules of the consumer, not production schedules. "The greatest factor affecting how típica vendors sell in Antigua is the number of tourists who visit . . . The greatest numbers of vendors are visible on Saturdays and Sundays because this is when the most national and foreign tourists visit (Little 2004: 94).

\section{Ecological Integration}

The ecological regions we used in our model stretch across four distinct biomes. Two of these are located in the Pacific coastal lowlands: the mangroves biome and the tropical and subtropical dry broadleaf forest biome. Only three of the 230 municipalities for which we collected data are located in mangrove zones: one in the Northern dry Pacific coast mangroves (Tognetti 2001), and two in the Tehuantepec/El Manchón mangroves (Valero 2001). These are moist areas, with good soil, in which the natural mangrove cover has been largely removed due to human activity in the last fifty years. Another eight municipalities lie in the Central-American Pacific dry forest, part of the tropical and subtropical dry broadleaf forests biome. These tropical forests have a long dry season often lasting five to eight months out of the year. This environment is also disappearing rapidly. These dry forests are more endangered than the tropical rainforests and are found only in a small portion of Guatemala (Andraka 2001). 
Three biomes are found in the Guatemalan highlands. The core area of the highlandscontaining 141 municipalities_-belongs to the Central-American Pine-Oak forest eco-region, part of the Tropical and subtropical coniferous forests biome (Powell 2001). The Chiapas Depression dry forest zone, an eco-region in the tropical and subtropical dry broadleaf forests biome (Valero 2001), contains three municipalities.

Three eco-regions form part of the tropical and subtropical moist broadleaf forests biome. First, the Central-American montane forest zone, located in areas subject to heavy rainfall and year-round cloud cover, contains 36 municipalities (Powell 2001). Second, the Sierra Madre de Chiapas moist forests eco-region consists of broadleaf forests that function as a transition region between the pine-oak forests and dry forests on the Western slopes of the mountains (Valero 2001), and contains 37 municipalities. Finally, in the north, as the highlands fall to the Petén lowlands, the Petén-Veracruz moist forest eco-region contains two municipalities. This region has only recently been settled but is attractive for tropical agriculture (Valero 2001).

\section{Cultural Integration}

The actors within a market system are much more than abstract buyers and sellers; they are human beings with a full complement of other characteristics, such as class, occupation, ethnicity, and gender. Most sellers in highland periodic markets produce food and handicrafts at their rural homesteads and make a trip into town to sell their products. The periodic market allows them to avoid selling to a middleman, and so enables them to obtain a better price for their products. Most sellers are women, and marketing is one of their contributions to a diversified set of strategies-including growing their own food, working for wages on coastal plantations, and selling handicrafts—-that allows a peasant household to maintain itself in the highlands (Swetnam 1989: 92).

There are more than thirty Mayan languages spoken throughout Guatemala, Mexico, and Belize (Richards 2003). Figure 6 shows the phylogenetic relationships among these languages (from Grimes 2000). Guatemalan market vendors are both Ladinos and Indians. A Ladino, in the Guatemalan context, is a person who speaks only Spanish, whether of white, mestizo, or Indian ancestry. Ladinos live mostly in the lowlands or in urban areas. Most Indians live in the highland regions, and make up almost all of the rural population in the highlands. These two classes of people rarely come together in social or economic context outside of the marketplace.

Although the Ladinos and the Indian populations are generally separated in a social context, they do at times form bonds within the marketplace. Often, relationships such as these 
consist based on the cultural identity of market participants. Self perceptions often change in the marketplace, especially for the Indians of Guatemala. When asked to describe themselves by other market participants, they may describe themselves in terms of their hometown, their native Mayan language, or their Mayan heritage in general (van der Berghe 1968). However, when dealing with the government or market authorities, these same people will describe themselves as first and foremost a Guatemalan in order to avoid discrimination. This presents the essential identity dilemma for the Indians. They want to completely embody the "Other" identity (the Indian) in the marketplace and especially in front of tourists; but when approached by the higher rungs of the social ladder, the Mayans immediately attempt to blend in. In essence, inside the marketplace, class unites both Ladinos and Indians as "poor", however, outside of the marketplace, and to some extent, inside the marketplace, ethnicity and class separate the vendors.

\section{Empirical Model and Data}

The objective of this study is to determine the effects of physical, environmental, and cultural differences on the number of vendors that are sent from one Guatemalan town to another. Also, we attempt to determine the effect that tourism has had on vendor migration. A gravity equation (Haynes and Fotheringham 1984), in log-linear form, will be used in order to relate these different characteristics of both the source towns and destination towns. The number of vendors will be a function of the characteristics of source towns, transactions costs, and characteristics of the destination towns:

$$
Y_{i j}=\left(A \prod_{\substack{k \in \text { ource } \\ \text { variables }}} X_{i k}^{\alpha_{k}}\right)\left(\prod_{\substack{f \in \text { flow } \\ \text { variables }}} D_{i j f}^{\alpha_{f}}\right)\left(\prod_{\substack{r \in \text { destination } \\ \text { variables }}} Z_{j r}^{\alpha_{r}}\right)
$$

Where $Y_{i j}$ denotes the number of vendors sent from municipality $i$ to municipality $j$, the $X_{i k}$ are variables measuring attributes of source regions, the $D_{i j f}$ are flow variables, and the $Z_{j r}$ denote variables pertinent to destination regions: In log linear form, the model would appear as in Equation 2 below:

$$
\ln \left(Y_{i j}\right)=\alpha_{0}+\sum_{\substack{K \in \text { source } \\ \text { variables }}} \alpha_{K} \ln \left(X_{i k}\right)+\sum_{\substack{f \in \text { flow } \\ \text { variables }}} \alpha_{f} \ln \left(D_{i j f}\right)+\sum_{\substack{r \in \text { destination } \\ \text { variables }}} \alpha_{r} \ln \left(Z_{j r}\right)
$$

Descriptive statistics for the variables can be found in Table 1, along with a short description and data sources. There are 15 destination markets, $j$, and 230 potential source towns, $i$, in the data used for estimation, though only 85 source towns actually sent vendors to the 15 markets. We do 
not estimate flows from a town to itself, so the number of observations in our data is $15^{*}(230-1)$ $=3,435$.

Number of Vendors The dependent variable is the number of vendors sent from a source town to a destination town. These data were gathered by the ethnographer Tadayoshi Murakami (1997) in interviews of vendors during market days in a sample of market towns in Guatemala. ${ }^{1}$ Figure 2 shows the 15 censused markets, all of which are centered around Lake Atitlan, as well as the 68 home municipalities reported by vendors in at least one of the censused markets. To specify correctly the gravity model, even municipalities within the region sending zero vendors must be included in the set of observations; the map shows the location of these 147 municipalities.

Type of Market The institution of periodic markets evolved to integrate Guatemala's rural areas with urban areas, and to integrate the country's different ecological zones. But tourists have long been fascinated by these markets and many vendors today focus on selling handicrafts, particularly clothing, to tourists. From a website promoting Guatemalan markets to tourists (guatemalaturistica.com 2007) we found a list of 13 “don't miss” (Mercados de no perderse) markets, and 57 other "major" markets considered worthy of calling to the attention of tourists. Thus, 161 of our 230 towns had markets not mentioned on this website, and these could be considered to be relatively untouched by tourism. Two of our 15 censused markets (Chichicastenango and Sololá) are “don’t miss” markets, and three are unmentioned "minor" markets (San Pedro La Laguna, Chicacao, and Mazatenango).

Since our intention is to determine if the pattern of vendor movement is significantly different for tourist markets we created a dummy variable for vendors whose source town is a "don't miss" market, and another for destination markets that are "don't miss.” We then used the destination market dummy in interaction terms with all other independent variables to see if the estimated coefficients are the same for major tourist markets as they are for other markets. Our final specification is given below in equation 3 :

\footnotetext{
${ }^{1}$ The Guatemalan political system divides authority between the national level, the department level, and the municipal level. Every area in the country, no matter how rural, is included in a municipality. Within a municipality there may be aldeas (hamlets) large enough to be considered towns in their own right; nevertheless, population statistics are only available at the municipal level. Since Murakami conducted interviews in a number of aldeas within the same municipality, these were aggregated to the municipal level, giving a total of 15 municipalities for which we have information about the origin of vendors.
} 


$$
\begin{aligned}
\ln \left(Y_{i j}\right) & =\alpha_{0}+\sum_{\substack{K \in \text { Source } \\
\text { variables }}} \alpha_{K} \ln \left(X_{i k}\right)+\sum_{\substack{f \in \text { flow } \\
\text { var iables }}} \alpha_{f} \ln \left(D_{i j f}\right)+\sum_{\substack{r \in \text { destination } \\
\text { var iables }}} \alpha_{r} \ln \left(Z_{j r}\right) \\
& +\beta_{0} t_{j}+\sum_{\substack{K \in \text { source } \\
\text { variables }}} \beta_{K} t_{j} \ln \left(X_{i k}\right)+\sum_{\substack{f \in \text { flow } \\
\text { var iables }}} \beta_{f} t_{j} \ln \left(D_{i j f}\right)+\sum_{\substack{r \in \text { destination } \\
\text { variables }}} \beta_{j} t_{j} \ln \left(Z_{j r}\right)
\end{aligned}
$$

where $t_{\mathrm{j}}$ is the dummy for the “don’t miss” major tourist market.

Population A larger town will both send and attract more vendors. One question, though, is whether vendors tend to travel up or down the central place hierarchy. That is, do higher order places send out vendors to lower order places, or do vendors from lower order places market their goods in higher order centers. Perhaps the pattern is different for tourist markets, since the handicraft products sought by tourists are typically produced in rural areas that are the lowest in the central place hierarchy.

Percent Female Population Most actual vendors are female. Females may be especially effective vendors in tourist markets: women dress in traje in order to play the role of the "touristconceptualized” Indian and their sales benefit (Little 2004). Selling in markets is usually not a full-time specialized occupation, but is rather one of the strategies employed by a peasant household in order to make a living (Swetnam 1989: 92). Another strategy common in the Guatemalan highlands is for men to work seasonally on large coastal farms (Adams 1970). Areas of the country with a high percent of the population female would thus tend to be poor areas with men working on the coast. In these poor areas, households would be more likely to pursue the strategy of selling in markets, an activity which would occupy the female members while the males are elsewhere.

Percent Urban Population Municipalities differ in the percent of their population that is rural. A municipality with a large rural hinterland would be more likely to have a market with many rural residents disposing of surplus production, so that the supply of rural products would be high relative to demand, and prices low. Thus one might expect vendors to leave such areas and travel to municipalities with a higher percent urban population, where prices are higher. This might be especially true for tourist markets, where rural handicrafts (mostly textiles) have a relatively high value to weight ratio, and are not perishable, making them able to be profitably transported. But this would be true only if producers carry out the final sale. If middlemen purchase goods in less urbanized municipalities, and then carry goods back to their home (more urbanized) markets, we would find that traveling vendors come predominantly from more urbanized municipalities. 
Own Vendors as Percent Own Population $\quad$ In some municipalities a relatively high percentage of the population participates as vendors in the local market. When this occurs, is it because the market is an especially lucrative one? If so, vendors from other municipalities should also arrive in especially large numbers. Or does this occur because opportunities for other employment are low, in which case one would expect hometown vendors to crowd out vendors from elsewhere, so that few arrive.

Road Density Municipalities differ in the degree to which they are integrated into the Guatemalan road network. Figure 4 shows the variation in road quality in the area around Lake Atitlan; the roads range from paved all-weather roads to paths passable by foot or horseback. Our measure of road density is constructed by identifying the midpoint of all road segments in Guatemala, then assigning that point a value equal to the length of the segment times a weight for road quality (100 for a paved road, 70 for an all-weather unpaved road, 50 for a dry-weather road, 10 for dirt track passable by automobile, and 1 for a footpath), as below.

$$
r d_{j}=\sum_{k} \frac{l_{k} w_{k}}{\min \left(1, d_{j k}\right)^{2}} \quad \forall d_{j k} \leq 15
$$

Where $r d_{j}$ is the road density of municipality $j, l_{k}$ is the length of road segment $k, w_{k}$ is the weight for road segment $k$, and $d_{j k}$ is the distance between the municipality's capital town and the midpoint of road segment $k$. All distances less than one mile are set equal to one, and no distances greater than 15 miles are included in the set of road segments.

Physical Distance Transaction costs will always increase as distance increases. The more interesting question here is whether the friction imposed by distance is greater or smaller for tourist markets as compared to other markets.

Linguistic Proximity Linguistic proximity can serve as a proxy for cultural proximity, since language is not only a part of culture but the vehicle by which culture is transmitted. Ceteris paribus, market exchanges between speakers of closely related languages would have lower transactions costs since the parties would share more cultural context. The Mayan languages of Guatemala stand in a well understood phylogenetic relationship with one another, so that it is possible to speak of the distance between languages. Using a database that presents taxonomic relationships between languages for each country (Grimes 2000), and employing the methods detailed in (Eff 2004), a language proximity matrix was created using the following formula:

$$
S_{r k}=\frac{\partial_{x}-\partial_{r k}+1}{\partial_{x}+1}
$$


where $S_{r k}$ is the similarity between language $r$ and language $k, \partial_{x}$ is the length of the longest path in the language family (i.e., the length of the longest path to the common ancestor of the entire family), and $\partial_{r k}$ is the length of the longest path to the nearest common ancestor of language $r$ and language $k$. Proceeding in this way, one can calculate a proximity measure between each pair of languages within the Mayan language family. Since there are no links among the major language families, each Mayan language has a similarity of zero with Spanish. The similarity between each language will thus always lie between zero and one. It will equal zero only when the two languages lie in different families, and will equal one only when a language is compared with itself.

A recent linguistic atlas (Richards 2003) shows the geographical extent of the different languages of Guatemala, as shown in Figure 5. A language was assigned to each of the 230 towns, based on the language area in which it fell on the atlas. The linguistic distance matrix was then used to calculate the distance between each pair of towns.

Altitude Guatemala has strikingly different ecological zones, and one way to capture these is by considering altitude. Figure 1 shows the topography in the area containing the censused markets and most of the towns of vendor origins. The coast is of low elevation, a warm area that produces tropical products. The high elevation altiplano is an area of small hardscrabble peasant holdings, the home of most Maya, where pine groves and wheat fields can be found. In between, on the slopes leading to the coast and in basins throughout the altiplano, is a temperate zone, notable mostly for its coffee farms. One would expect markets to integrate these different altitude zones, so that outside vendors arriving at a market would sell produce not available locally, and thus would primarily arrive from municipalities at either higher or lower elevations.

Ecological Proximity Another way to consider the function of markets in integrating different ecological zones is to construct an ecological proximity index. The World Wildlife Fund has produced a world map of ecological zones (Olson, et al 2000) available as a GIS layer. The map divides the planet's land area into 867 unique ecoregions (15 of which are in Guatemala), and each of these are classified into one of 14 biomes (five of which are in Guatemala). Each town is assigned the biome and ecoregion in which it is located. A pair of towns in the same ecoregion is given a proximity score of one. A pair in the same biome but different ecoregions have a proximity score of 0.5 ; a pair in different biomes have a score of zero.

Slope Areas with flat slopes should have good agricultural potential, whereas peasants in areas with steep slopes may have to supplement farming of their own plots with other work, such as 
selling handicrafts in markets. Using a raster coverage of slope in Guatemala (United States, United States Geological Survey 2007), we calculated the mean slope in a radius of two miles for each of the 230 towns.

\section{Results}

Table 2 reports the estimated coefficients for both our unrestricted and restricted models. Standard errors were calculated using a bootstrap (Burr 1994): sampling with replacement from our original data, we created a new data set with the same number of observations and reran our regressions, saving the estimated coefficients. We repeated this 300 times, each time with a new data set, giving us 300 sets of estimated coefficients. The standard deviation, over the 300 estimates, of each estimated parameter serves as our bootstrap standard error. Using these to calculate t-statistics, we dropped all independent variables with a p-value above 0.10 , to create a restricted model. An F-test on the restrictions failed to reject the null hypothesis that the dropped variables did not belong in the model (p-value $=0.77953$ ).

Table 3 uses the estimated coefficients from the restricted model in Table 2 to show how the coefficients for the two “don't miss” markets differ from the other 13 markets. The coefficients for non-tourist markets equal the estimated parameters $\alpha$ from equation 3. We add the estimated parameters $\alpha$ and $\beta$-that is, the original parameter plus the parameter from the interaction term - to get the value of the coefficients for tourist markets. The parameters $\beta$ constitute a test for the difference in the coefficients between tourist and non-tourist markets.

Distance causes the number of vendors traveling to a periodic market to decay, and the rate of decay is greater for tourist markets. Thus tourist markets have a more constricted supply area, whether because local vendors actively discourage outsiders from the lucrative market, or because tourists themselves are eager to buy local products.

The populations of the source and destination towns affect the flow of vendors as expected: the larger the population, the greater the flow. The effect is somewhat intensified for the major tourist markets, however, so that the increase in vendors for an increase in source town population will be greater for a tourist market than a non-tourist market.

A town in which a large percentage of its own population is vendors in its own periodic market will draw disproportionately more vendors from other towns. Evidently, some markets face a higher effective demand than others, even after controlling for population. This effect is of the same size in both tourist and non-tourist markets, so it is not simply the additional demand of tourists that prompts more local residents and more outsiders to sell in these markets. 
Vendors arrive in smaller numbers from municipalities that are in close ecological proximity to the local market, a result that is identical for both tourist and non-tourist markets. Similarly, vendors arrive in smaller numbers from municipalities that lie closer together in altitude, though only for tourist markets. These results support the notion that periodic markets integrate the very different ecological zones of Guatemala via the activities of traveling vendors, who bring products that cannot be produced locally.

A source municipality with high average hill slope will produce more vendors than a more level municipality. This result holds equally for tourist and non-tourist markets, and suggests that vendors are more likely to come from an area of small hardscrabble farms clinging to hillsides, where selling in markets provides an important element in a diversified strategy of earning income.

A similar story seems to explain the result that a source municipality with females making up a higher percentage of its population will send more vendors. The coefficients in Table 3 are all elasticities, making comparison possible, and the elasticity for percent female is by far the largest-nearly four times the size of the elasticity for distance. As mentioned above, the municipalities containing a disproportionate number of females are likely to be those areas that send seasonal (male) agricultural labor to the coast. These areas contain small peasant holdings whose inhabitants carry out a diversified set of activities in order to survive. One of those activities is selling in markets, and marketing happens to be an activity predominantly carried out by females.

Transportation infrastructure apparently does not facilitate vendor movement: the greater the source municipality road density, the fewer vendors are sent. In addition, vendors are more likely to come from a source municipality with road density values close to those of the destination market. There are no differences in the response of tourist and non-tourist markets to these variables. Periodic markets are clearly a phenomenon of the periphery: vendors are apparently drawn from more isolated populations, who engage in this marketing activity as part of a diversified strategy of making a living.

A source municipality is likely to send more vendors to a non-tourist market the higher the percentage of its population that is urban. The smaller the difference in percentage urban between the source and destination towns, the more vendors are sent. Thus, in the traditional, non-tourist markets, it appears that the main flow of vendors is among municipalities with more urbanized populations. These results appear to indicate a pattern of specialization and trade in a system of towns, a pattern that Smith had said is not characteristic of traditional markets in Guatemala. 
But for a tourist market the situation is reversed: more vendors are likely to come from a municipality whose population is more rural; and the greater the difference in percent urban between source and destination, the more vendors are sent. Thus, in tourist markets, the main movement of vendors appears to emanate from municipalities with predominantly rural populations and flow towards markets in towns with more urban populations. These results fit our prediction that producers in very rural municipalities would seek better prices by selling in more urbanized municipalities, and that this tendency might be especially pronounced with products marketed to tourists, such as textiles, since these have a high value to weight ratio and are easily transported.

Finally, we consider the linguistic proximity between source and destination towns. For nontourist markets the effect is negative but (barely) insignificant, but for tourist markets the effect is clearly negative: the less similar the languages of the source and destination towns, the more vendors sent. This result suggests that periodic markets do not wall off the different Mayan language groups from each other, but that rather they serve to integrate the different communities, by bringing them together in markets.

\section{Summary and Conclusions}

The prevalent view of the system of markets in highland Guatemala owes much to the work of Carol Smith in the 1970s. Smith applied central place theory to this environment and concluded that the market system largely consisted of rural Indian peasants who sold foodstuffs for the consumption of Ladino town-dwellers, but who purchased little from higher order centers except for items they could not produce themselves, such as iron tools. She characterized the principal towns as administrative centers, and found that the main flows between the towns and higher order centers took place via commercial establishments, not periodic markets. She found little regional specialization and exchange among these highland towns, and instead found that most exchanges were directed toward the higher centers of Quetzaltenango or Guatemala City.

Murakami's (1997) research found, however, a large number of vendors moving between municipalities - a pattern of lateral movement that did not fit Smith's description of vertical movement. Swetnam $(1989,1990)$ had emphasized the role that selling in periodic markets played as part of a diversified strategy rural peasants use to survive, but many questions about the movement of vendors were still unanswered: were these movements founded on ecological specializations, on other types of specializations? Are vendors moving in search of higher prices? Do language barriers funnel vendors toward specific markets? Has the influx of tourists changed the role of period markets? We sought to address these questions. To that end, we estimated a 
gravity model, in which the dependent variable was the number of vendors, originating in one of 230 potential source municipalities, who were selling in markets in one of 15 towns censused in 1997 by the Japanese ethnographer Tadayoshi Murakami. We added to these data other data from the Guatemalan census, from various GIS layers, and from additional sources such as the linguistic atlas for Guatemala.

We find that traveling vendors in these periodic markets do indeed integrate Guatemala's ecological zones, bringing in products that cannot be produced locally. Additionally, in markets less affected by tourism, there appears to be some non-ecological specialization and exchange, suggesting that Smith's view of towns dealing only with higher order centers (and then only through commercial establishments, rather than periodic markets) may no longer be correct. Language barriers do not funnel vendors toward specific markets, but instead the markets serve as a place in which the different ethnic groups meet, which suggests that periodic markets also integrate the country ethnically.

Our estimates give a great deal of support to the view of Swetnam that participation in markets is part of a diversified set of activities used by rural peasants. Vendors are heavily drawn from areas with high hill slopes, poor road access, and with a high percentage of the population that is female. This last characteristic is significant since most vendors are female, and the areas with the greatest number of absent males are those where the males work seasonally as farm laborers on Guatemala’s Pacific coast—another of the strategies used by rural peasants to survive.

The effect of tourists on markets is perhaps a bit contradictory. On the one hand, the number of vendors going to major tourist markets decays quite rapidly with distance-more rapidly than traditional markets—suggesting that tourist markets have relatively small supply areas. On the other hand, vendors traveling to tourist markets—compared to vendors traveling to traditional markets-are less likely to come from a municipality with the same language as the market town, suggesting a somewhat wider supply area. Similarly, vendors traveling to tourist markets are much more likely to come from more rural municipalities than are vendors in traditional markets. This too seems to suggest a relatively wide supply area, and fits with the notion that tourist goods have a high value to weight ratio, should be easily transported, and rural producers would find it worthwhile to bring them fairly long distances to a market where a good price can be found. 


\section{References}

Adams, Richard Newbold. (1970). Crucifixion by Power; Essays on Guatemalan National Social Structure, 1944-1966. Austin: University of Texas Press.

Andraka, Sandra. (2001). "Central American dry forests (NT0209)." www.worldwildlife.org/wildworld/profiles/terrestrial/nt.html

Annis, Sheldon. (1987). God and Production in a Guatemalan Town. Austin: University of Texas.

Bromley, R. J., Richard Symanski, and Charles M. Good. (1975). "The Rationale of Periodic Markets.” Annals of the Association of American Geographers 65.4, 530-537.

Bromley, R. J., and Richard Symanski. (1974). "Marketplace Trade in Latin America.” Latin American Research Review 9.3, 3-38.

Burr, Deborah. 1994. "A Comparison of Certain Bootstrap Confidence Intervals in the Cox Model,” Journal of the American Statistical Association, 89, 1290-1302.

Comisión Centroamericana del Ambiente y Desarrollo. (2007). "Base de Datos SIG de Mesoamérica / CCAD-BM." http://www.ccad.ws/documentos/mapas.html

Eff, E.A. (2004). Spatial, Cultural, and Ecological Autocorrelation in U.S. Regional Data. MTSU Department of Economics and Finance Working Papers. September 2004. http://www.mtsu.edu/ berc/working/autocorrelationinUSregional data.pdf

Grimes, Barbara (editor). 2000. Ethnologue: Languages of the World (Fourteenth edition). Dallas: SIL International.

Guatemala (1994). X Censo Nacional de Población y V de Habitación. Características generales de la población, CUADRO 5. POBLACION TOTAL POR AREA URBANA-RURAL Y SEXO, SEGUN DEPARTAMENTO Y MUNICIPIO. http://ccp.ucr.ac.cr/bvp/censos/zip/guate/index.htm

Guatemalaturistica.com (2007). Mercados del Altiplano Guatemalteco. http://guatemalaturistica.com/mercados.html

Haynes, Kingsley E. and A. Stewart Fotheringham. (1984). Gravity and Spatial Interaction Models. Beverly Hills: Sage Publications.

Little, Walter E. (2004). Mayas in the Marketplace: Tourism, Globalization, and Cultural Identity. Austin: University of Texas.

McBride, George M. and Merle A. McBride. (1942). "Highland Guatemala and Its Maya Communities.” Geographical Review 32.2, 252-268.

McDowell, Paul. (1976). "Guatemalan Stratification and Peasant Marketing Arrangements: A Different View.” Man 11.2, 273-278.

Mendoza Alvarado, Carlos Antonio. (1999). Aproximación al funcionamiento de los mercados indígenas de Guatemala: Consideraciones económicas sobre el mercado de Tecpán Guatemala. Tesis para Licenciado en Economía. Guatemala: Universidad Francisco Marroquín, Facultad de Ciencias Económicas. http://web.ufm.edu.gt/ccee/carlosma/

Murakami, Tadayoshi. (1997). "Los mercados y pueblos mayas en el altiplano de Guatemala." Informe de las Investigaciones Etnológicas en el Centro y Sur de Guatemala 1991-1994. Tokyo: Museo de Tabaco y Sal. 
Olson, David M., Eric Dinerstein, Eric D. Wikramanayake, Neil D. Burgess, George V.N. Powell, Emma C. Underwood, Jennifer A. D’Amico, Illanga Itoua, Holly E. Strand, John C. Morrison, Colby J. Loucks, Thomas F. Allnutt, Taylor H. Ricketts, Ymiko Kura, John F. Lamoreaux, Wesley W. Wettengel, Preshant Hedao, and Kenneth R. Kassem. “Terrestrial Ecoregions of the World: A New Map of Life on Earth.” BioScience 51.11 (2001): 933-938.

Pearce, Kenneth. (1984). The View from the Top of the Temple: Ancient Maya Civilization and Modern Maya Culture. Abuquerque: University of New Mexico.

Powell, George and Sue Palminteri. (2001). "Central American montane forests (NT0112)." www.worldwildlife.org/wildworld/profiles/terrestrial/nt.html

Powell, George, Sue Palminteri, Claudia Locklin, and Jan Schipper. (2001). "Central American pine-oak forests (NT0303).” www.worldwildlife.org/wildworld/profiles/terrestrial/nt.html

Richards, Michael. (2003). Atlas Lingüístico de Guatemala. Sepaz: Editorial Serviprenza, S.A..

Smith, Carol A. (1975). "Examining Stratification Systems Through Peasant Marketing Arrangements: An Application of Some Models from Economic Geography.” Man 10.1, 95-122.

(1976). "Causes and Consequences of Central-Place Types in Western Guatemala.” Regional Analysis: Economic Systems. 1, 255-300.

. (1978). "Beyond Dependency Theory: National and Regional Patterns of Underdevelopment in Guatemala.” American Ethnologist 5.3, 574-617.

. (1984). "Local History in Global Context: Social and Economic Transitions in Western Guatemala.” Comparative Studies in Society and History 26.2, 193-228.

Swetnam, John J. (1978). "Interaction Between Urban and Rural Residents in a Guatemalan Marketplace.” Urban Anthropology. 7.2: 137-153.

(1990). "Migratory Patterns of Vendors in a Guatemalan Market.” Ethnology. 29.3: 261-273.

. (1989). "What Else Did Indians Have to Do with Their Time? Alternatives to Labor Migration in Prerevolutionary Guatemala.” Economic Development and Cultural Change. 38.1: 89-112

Thomas, Christopher R. and S. Charles Maurice. (2005). Managerial Economics. Boston: McGraw Hill.

Tognetti, Sylvia and Christine Burdette. (2001). "Northern Dry Pacific Coast mangroves (NT1425).” www.worldwildlife.org/wildworld/profiles/terrestrial/nt.html

United States, USGS International Program at EROS data center. (2007). DGF Project of the Inter-American Biodiversity Information Network; Shuttle Radar Topography Mission derived data. http://edcintl.cr.usgs.gov/iabin_datadownload.html\#Guatemala

Valero, Alejandra and Christine Burdette. (2001). "Tehuantepec-El Manchon mangroves (NT1435).” www.worldwildlife.org/wildworld/profiles/terrestrial/nt.html

Valero, Alejandra, Jan Schipper, and Tom Allnutt. (2001). “Chiapas Depression dry forests (NT0211).” www.worldwildlife.org/wildworld/profiles/terrestrial/nt.html

(NT0154).” www.worldwildlife.org/wildworld/profiles/terrestrial/nt.html 
(2001). "Sierra Madre de Chiapas moist forest (NT0162).” www.worldwildlife.org/wildworld/profiles/terrestrial/nt.html

Van den Berghe, Pierre L. (1968). "Ethnic Membership and Cultural Change in Guatemala.” Social Forces 46.4, 514-522.

Watanabe, John M. (1992). Maya Saints and Souls in a Changing World. Austin: University of Texas. 
Table 1: Descriptive Statistics

\begin{tabular}{|c|c|c|c|c|c|c|}
\hline Variable & Description (source) & Max & Min & Mean & Std Dev & $\begin{array}{l}\text { weighted } \\
\text { mean }\end{array}$ \\
\hline vendr2q & $\begin{array}{l}\text { number vendors from source } \\
\text { selling in destination (a) }\end{array}$ & 118 & 0 & 0.7154921 & 4.978984 & \\
\hline selfp & $\begin{array}{l}\text { proportion of destination town } \\
\text { population selling as vendors (a,b) }\end{array}$ & 0.025 & 0.001 & 0.011 & 0.008 & 0.012 \\
\hline ladino & $\begin{array}{l}\text { source town is Spanish-speaking } \\
\text { (c) }\end{array}$ & 1.000 & 0.000 & 0.057 & 0.231 & 0.002 \\
\hline top & $\begin{array}{l}\text { destination town is dont-miss } \\
\text { market (d) }\end{array}$ & 1.000 & 0.000 & 0.133 & 0.340 & 0.199 \\
\hline intop & $\begin{array}{l}\text { source town is dont-miss market } \\
\text { (d) }\end{array}$ & 1.000 & 0.000 & 0.056 & 0.230 & 0.306 \\
\hline dist & $\begin{array}{l}\text { physical distance between source } \\
\text { and destination towns (h) }\end{array}$ & 102.9 & 1.1 & 40.3 & 19.9 & 15.7 \\
\hline ecol & $\begin{array}{l}\text { ecological proximity between } \\
\text { source and destination towns (e) }\end{array}$ & 1.000 & 0.000 & 0.463 & 0.482 & 0.636 \\
\hline prox & $\begin{array}{l}\text { linguistic proximity between } \\
\text { source and destination towns (c) }\end{array}$ & 100.0 & 0.0 & 57.7 & 30.7 & 82.1 \\
\hline rpop & own population (b) & 823,301 & 1,258 & 26,191 & 59,743 & 40,747 \\
\hline qрор & destination to & 75,797 & 4,963 & 27,284 & 18,845 & 27,096 \\
\hline dpop & $\begin{array}{l}\text { population: destination minus } \\
\text { source (b) }\end{array}$ & 74,539 & 818,338 & 1,093 & 62,670 & $-13,651$ \\
\hline rpurban & percent urban source town (b) & 1.0000 & 0.0125 & 0.3109 & 0.2545 & 0.3526 \\
\hline qpurban & percent urban destination town (b) & 0.9955 & 0.0481 & 0.4094 & 0.2785 & 0.3766 \\
\hline dpurban & $\begin{array}{l}\text { pct. urban: destination minus } \\
\text { source (b) }\end{array}$ & 0.9830 & -0.9519 & 0.0985 & 0.3782 & 0.0240 \\
\hline rpmujer & percent female source town (b) & 0.5488 & 0.4812 & 0.5047 & 0.0107 & 0.5087 \\
\hline qpmujer & $\begin{array}{l}\text { percent female destination town } \\
\text { (b) }\end{array}$ & 0.5170 & 0.4890 & 0.5044 & 0.0087 & 0.5043 \\
\hline dpmujer & $\begin{array}{l}\text { pct. female: destination minus } \\
\text { source (b) }\end{array}$ & 0.0358 & -0.0598 & -0.0003 & 0.0138 & -0.0044 \\
\hline rslope & average hill-slope source town (f) & 32.3 & 1.3 & 11.5 & 6.8 & 11.6 \\
\hline qslope & $\begin{array}{l}\text { average hill-slope destination } \\
\text { town (f) }\end{array}$ & 18.7 & 3.5 & 11.1 & 5.1 & 12.1 \\
\hline dslope & slope: destination minus source (f) & 17.4 & -28.8 & -0.4 & 8.5 & 0.6 \\
\hline rroad & 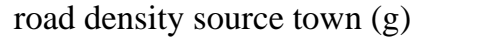 & 359.5 & 3.5 & 124.5 & 77.1 & 122.9 \\
\hline qroad & road density destination town (g) & 229.4 & 33.6 & 121.5 & 49.5 & 128.7 \\
\hline droad & $\begin{array}{l}\text { road density: destination minus } \\
\text { source (g) }\end{array}$ & 226.0 & -325.9 & -3.0 & 91.7 & 5.8 \\
\hline ralt & altitude of source town (h) & 3,186 & 1 & 1,542 & 794 & 1,811 \\
\hline qalt & altitude of destination town (h) & 2,641 & 342 & 1,574 & 750 & 1,549 \\
\hline dalt & $\begin{array}{l}\text { altitude: destination minus source } \\
\text { (h) }\end{array}$ & 2,640 & $-2,844$ & 31 & 1,094 & -262 \\
\hline
\end{tabular}

Notes: Weighted mean provides the mean value per vendor. Max, min, mean, and standard deviation are per flow from source town to destination town. N=3,434. Flows from town to itself are dropped. Sources: (a) Murakami 1997; (b) Guatemala 1994; (c) Richards 2003; (d) Guatemalaturistica.com 2007; (e) Olson, et al 2001; (f) United States, USGS International Program at EROS data center 2007; (g) Comisión Centroamericana del Ambiente y Desarrollo 2007; (h) http://www.heavens-above.com/countries.asp 
Table 2: Estimated Coefficients: Unrestricted and Restricted Models

\begin{tabular}{|c|c|c|c|c|c|c|c|}
\hline Variable & Description & $\begin{array}{l}\text { UnRes } \\
\text { Coef }\end{array}$ & $\begin{array}{l}\text { UnRes } \\
\text { Sterr }\end{array}$ & $\begin{array}{l}\text { UnRes } \\
\text { Pval }\end{array}$ & $\begin{array}{l}\text { Res } \\
\text { Coef }\end{array}$ & $\begin{array}{l}\text { Res } \\
\text { Sterr }\end{array}$ & $\begin{array}{l}\text { Res } \\
\text { Pval }\end{array}$ \\
\hline Intercept & Intercept & -5.582 & 1.362 & 0.000 & -6.366 & 1.320 & 0.000 \\
\hline & $\begin{array}{l}\text { dummy: destination town is dont- } \\
\text { miss market }\end{array}$ & -4.372 & 4.528 & 0.167 & & & \\
\hline intop & $\begin{array}{l}\text { dummy: source town is dont-miss } \\
\text { market }\end{array}$ & 0.355 & 0.062 & 0.000 & 0.360 & 0.060 & 0.000 \\
\hline ladino & $\begin{array}{l}\text { dummy: source town is Spanish- } \\
\text { speaking }\end{array}$ & -0.043 & 0.032 & 0.091 & & & \\
\hline ldist & $\begin{array}{l}\log \text { (physical distance between } \\
\text { source and destination towns) }\end{array}$ & -0.472 & 0.035 & 0.000 & -0.467 & 0.032 & 0.000 \\
\hline lecol & $\begin{array}{l}\log (\text { ecological proximity between } \\
\text { source and destination towns) }\end{array}$ & -0.068 & 0.030 & 0.013 & -0.077 & 0.026 & 0.002 \\
\hline llang & $\begin{array}{l}\log (\text { linguistic proximity between } \\
\text { source and destination towns) }\end{array}$ & -0.011 & 0.007 & 0.057 & -0.006 & 0.005 & 0.106 \\
\hline lsalt & $\log$ (altitude of source town) & -0.021 & 0.010 & 0.015 & -0.024 & 0.008 & 0.002 \\
\hline lselfp & $\begin{array}{l}\log \text { (percent of destination town } \\
\text { population selling as vendors) }\end{array}$ & 0.057 & 0.028 & 0.020 & 0.056 & 0.027 & 0.019 \\
\hline lspmujer & $\log$ (percent female source town) & 1.592 & 0.351 & 0.000 & 1.792 & 0.335 & 0.000 \\
\hline lspop & $\log$ (source town population) & 0.140 & 0.012 & 0.000 & 0.139 & 0.012 & 0.000 \\
\hline lspurban & $\log$ (percent urban source town) & 0.021 & 0.013 & 0.047 & 0.020 & 0.012 & 0.051 \\
\hline lsroad & $\log$ (road density source town) & -0.076 & 0.011 & 0.000 & -0.073 & 0.009 & 0.000 \\
\hline lsslope & $\log$ (average hill-slope source town) & 0.073 & 0.024 & 0.001 & 0.083 & 0.023 & 0.000 \\
\hline lstalt & $\begin{array}{l}\text { log(abs. diff. altitude destination } \\
\text { and source) }\end{array}$ & 0.008 & 0.008 & 0.163 & & & \\
\hline lstpurb & $\begin{array}{l}\log \text { (abs. diff. pct. urban destination } \\
\text { and source) }\end{array}$ & -0.016 & 0.009 & 0.037 & -0.015 & 0.008 & 0.030 \\
\hline lstroad & $\begin{array}{l}\log (\text { abs. diff. road density } \\
\text { destination and source) }\end{array}$ & -0.054 & 0.009 & 0.000 & -0.049 & 0.008 & 0.000 \\
\hline lstslope & $\begin{array}{l}\text { log(abs. diff. slope destination and } \\
\text { source) }\end{array}$ & 0.002 & 0.012 & 0.442 & & & \\
\hline ltpop & ) & 0.026 & .013 & 0.025 & 0.026 & 0.012 & 0.015 \\
\hline tldist & $\begin{array}{l}\text { Interaction term: intop*log(physical } \\
\text { distance between source and } \\
\text { destination towns) }\end{array}$ & -0.373 & 0.102 & 0.000 & -0.366 & 0.090 & 0.000 \\
\hline tlecol & $\begin{array}{l}\text { Interaction term: } \\
\text { intop*log(ecological proximity } \\
\text { between source and destination } \\
\text { towns) }\end{array}$ & -0.010 & 077 & 0.448 & & & \\
\hline tllang & $\begin{array}{l}\text { Interaction term: } \\
\text { intop*log(linguistic proximity } \\
\text { between source and destination } \\
\text { towns) }\end{array}$ & -0.034 & 0.015 & 0.012 & -0.030 & 0.011 & 0.005 \\
\hline tlsalt & $\begin{array}{l}\text { Interaction term: intop*log(altitude } \\
\text { of source town) }\end{array}$ & -0.030 & 0.026 & 0.128 & & & \\
\hline tlspmujer & $\begin{array}{l}\text { Interaction term: intop*log(percent } \\
\text { female source town) }\end{array}$ & 1.152 & 1.174 & 0.163 & & & \\
\hline tlspop & $\begin{array}{l}\text { Interaction term: intop* } \log \text { (source } \\
\text { town population) }\end{array}$ & 0.108 & 037 & 002 & 0.116 & 0.035 & 0.001 \\
\hline tlspurban & $\begin{array}{l}\text { Interaction term: intop*log(percent } \\
\text { urban source town) }\end{array}$ & -0.111 & 0.062 & 0.037 & -0.102 & 0.053 & 0.026 \\
\hline tlsroad & $\begin{array}{l}\text { Interaction term: intop*log(road } \\
\text { density source town) }\end{array}$ & 0.031 & 0.028 & 0.137 & & & \\
\hline
\end{tabular}




\begin{tabular}{llcccccc}
\hline Variable & Description & $\begin{array}{l}\text { UnRes } \\
\text { Coef }\end{array}$ & $\begin{array}{l}\text { UnRes } \\
\text { Sterr }\end{array}$ & $\begin{array}{l}\text { UnRes } \\
\text { Pval }\end{array}$ & $\begin{array}{l}\text { Res } \\
\text { Coef }\end{array}$ & $\begin{array}{l}\text { Res } \\
\text { Sterr }\end{array}$ & $\begin{array}{l}\text { Res } \\
\text { Pval }\end{array}$ \\
\hline tlsslope & $\begin{array}{l}\text { Interaction term: intop*log(average } \\
\text { tlstalt }\end{array}$ & 0.028 & 0.079 & 0.360 & & & \\
hill-slope source town) & $\begin{array}{l}\text { Interaction term: intop*log(abs. } \\
\text { tliff. altitude destination and source) }\end{array}$ & 0.042 & 0.023 & 0.034 & 0.053 & 0.020 & 0.004 \\
tlstroad & $\begin{array}{l}\text { Interaction term: intop*log(abs. } \\
\text { diff. pct. urban destination and }\end{array}$ & 0.115 & 0.040 & 0.002 & 0.115 & 0.042 & 0.003 \\
source) & $\begin{array}{l}\text { Interaction term: intop*log(abs. } \\
\text { diff. road density destination and }\end{array}$ & 0.034 & 0.031 & 0.135 & & & \\
tlstslope & $\begin{array}{l}\text { source) } \\
\text { Interaction term: intop*log(abs. } \\
\text { diff. slope destination and source) }\end{array}$ & -0.043 & 0.064 & 0.251 & & & \\
\hline
\end{tabular}

Notes: $\mathrm{N}=3,434$. Flows from town to itself are not used in estimation. F-statistic for dropping 11 variables in unrestricted model to achieve restricted model: 0.65779 (p-value=0.77953). R-squared restricted model: 0.3276. Standard errors for both unrestricted and restricted models are bootstrap standard errors, calculated from 300 bootstrap trials. 
Table 3: Tourist Markets and Other Markets Compared

\begin{tabular}{|c|c|c|c|c|c|c|c|}
\hline Variab & Description & $\begin{array}{l}\text { Other } \\
\text { market } \\
\text { coef }\end{array}$ & $\begin{array}{l}\text { Other } \\
\text { market } \\
\text { pval }\end{array}$ & $\begin{array}{l}\text { Tourist } \\
\text { market } \\
\text { coef }\end{array}$ & $\begin{array}{l}\text { Tourist } \\
\text { market } \\
\text { pval }\end{array}$ & $\begin{array}{l}\text { Tourist } \\
\text { minus } \\
\text { Other }\end{array}$ & Pval \\
\hline Intercept & Intercept & -6.366 & 0.000 & -6.366 & 0.000 & 0.000 & - \\
\hline ldist & $\begin{array}{l}\text { physical distance } \\
\text { between source and } \\
\text { destination towns }\end{array}$ & -0.467 & 0.000 & -0.833 & 0.000 & -0.366 & 0.000 \\
\hline lecol & $\begin{array}{l}\text { ecological proximity } \\
\text { between source and } \\
\text { destination towns }\end{array}$ & -0.077 & 0.000 & -0.077 & 0.000 & 0.000 & - \\
\hline llang & $\begin{array}{l}\text { linguistic proximity } \\
\text { between source and } \\
\text { destination towns }\end{array}$ & -0.006 & 0.103 & -0.036 & 0.000 & -0.030 & 0.000 \\
\hline lselfp & $\begin{array}{l}\text { percent of destination } \\
\text { town population selling } \\
\text { as vendors }\end{array}$ & 0.056 & 0.010 & 0.056 & 0.010 & 0.000 & - \\
\hline lspmujer & $\begin{array}{l}\text { percent female source } \\
\text { town }\end{array}$ & 1.792 & 0.000 & 1.792 & 0.000 & 0.000 & - \\
\hline lsslope & $\begin{array}{l}\text { average hill-slope } \\
\text { source town }\end{array}$ & 0.083 & 0.000 & 0.083 & 0.000 & 0.000 & - \\
\hline lstalt & $\begin{array}{l}\text { abs. diff. altitude } \\
\text { destination and source }\end{array}$ & 0.000 & - & 0.053 & 0.003 & 0.053 & 0.003 \\
\hline lsalt & altitude of source town & -0.024 & 0.003 & -0.024 & 0.003 & 0.000 & - \\
\hline lstpurb & $\begin{array}{l}\text { abs. diff. pct. urban } \\
\text { destination and source }\end{array}$ & -0.015 & 0.023 & 0.100 & 0.007 & 0.115 & 0.003 \\
\hline lspurban & $\begin{array}{l}\text { percent urban source } \\
\text { town }\end{array}$ & 0.020 & 0.050 & -0.082 & 0.047 & -0.102 & 0.020 \\
\hline lstroad & $\begin{array}{l}\text { abs. diff. road density } \\
\text { destination and source }\end{array}$ & -0.049 & 0.000 & -0.049 & 0.000 & 0.000 & - \\
\hline lsroad & $\begin{array}{l}\text { road density source } \\
\text { town }\end{array}$ & -0.073 & 0.000 & -0.073 & 0.000 & 0.000 & - \\
\hline ltpop & $\begin{array}{l}\text { destination town } \\
\text { population }\end{array}$ & 0.026 & 0.007 & 0.026 & 0.007 & 0.000 & - \\
\hline lspop & source town population & 0.139 & 0.000 & 0.255 & 0.000 & 0.116 & 0.000 \\
\hline
\end{tabular}

Notes: The coefficient estimates are drawn from the unrestricted model results presented in Table 2. The tourist market coefficients are the sum of the $\alpha$ and $\beta$ parameters in equation 3; the coefficients for other markets are the $\alpha$ parameters in equation 3. The last two columns show the difference between the two markets; the coefficients given here are the $\beta$ parameters in equation 3. Standard errors for both tourist and non-tourist markets are bootstrap standard errors, calculated from 300 bootstrap trials. 


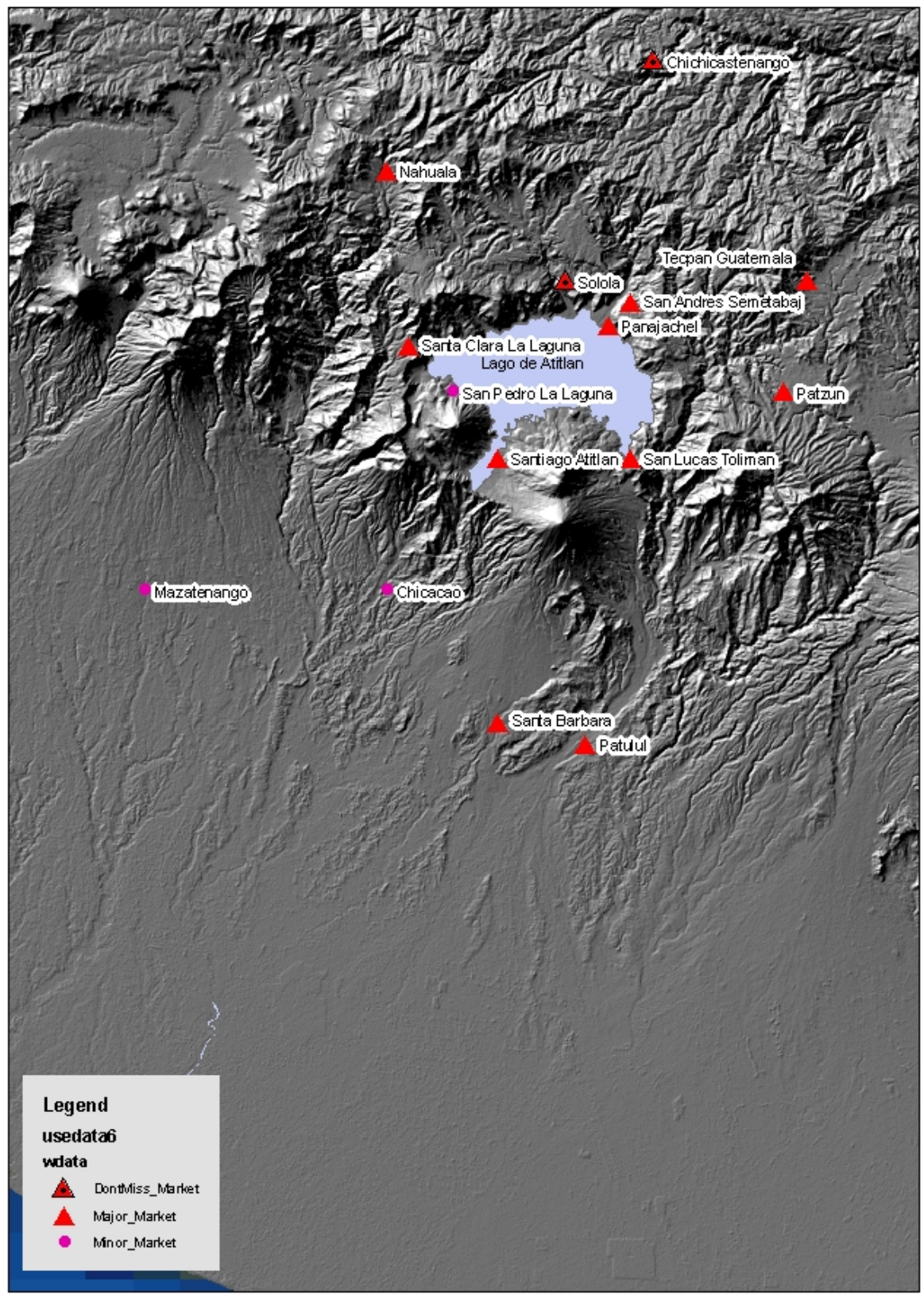

Figure 1: Topography of study area. 


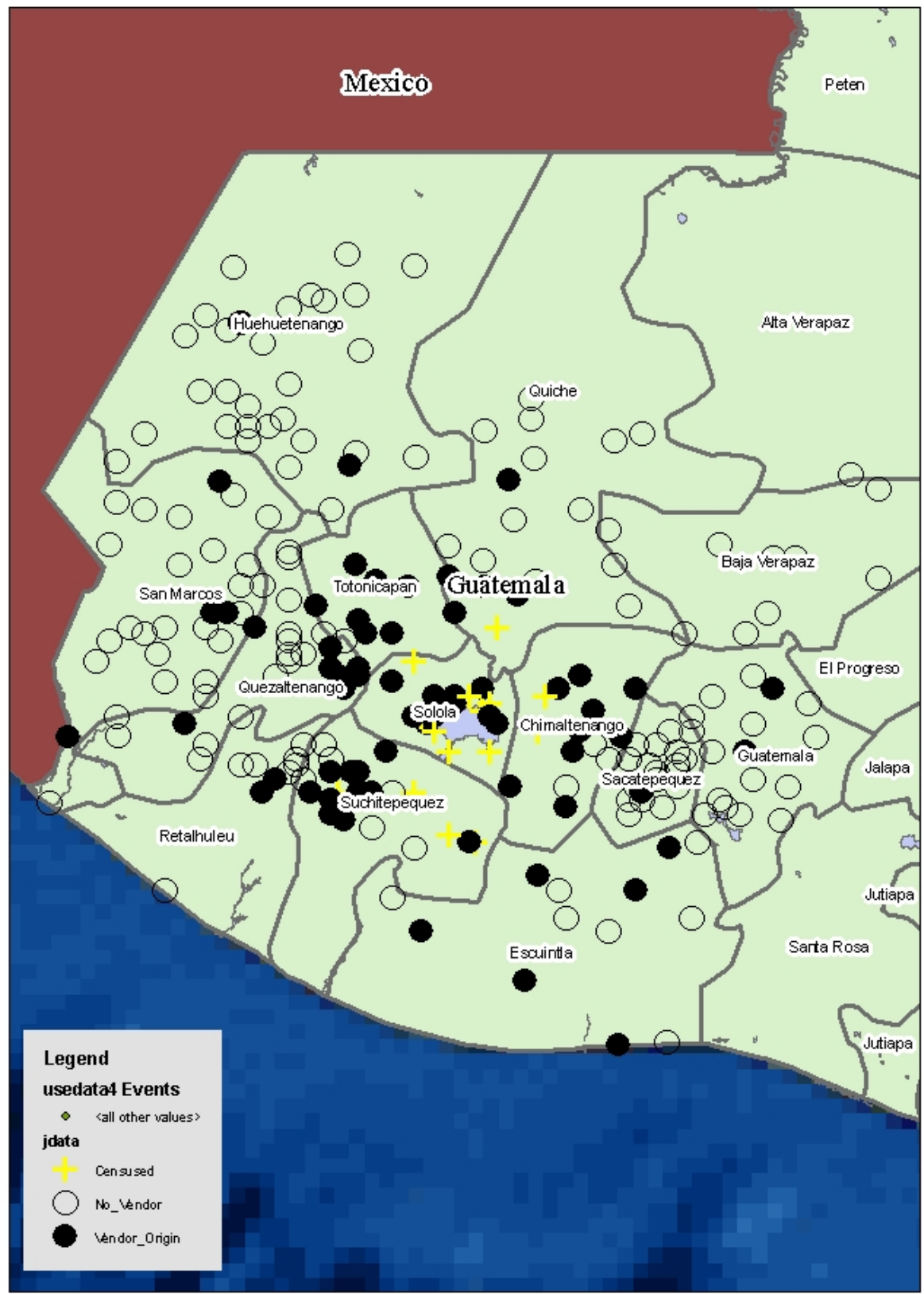

Figure 2: 15 censused markets, 68 towns sending vendors to censused market, and 147 towns not sending vendors. 




Figure 3: 13 “don't miss” markets, 57 major markets, and 161 towns not mentioned as major market. 


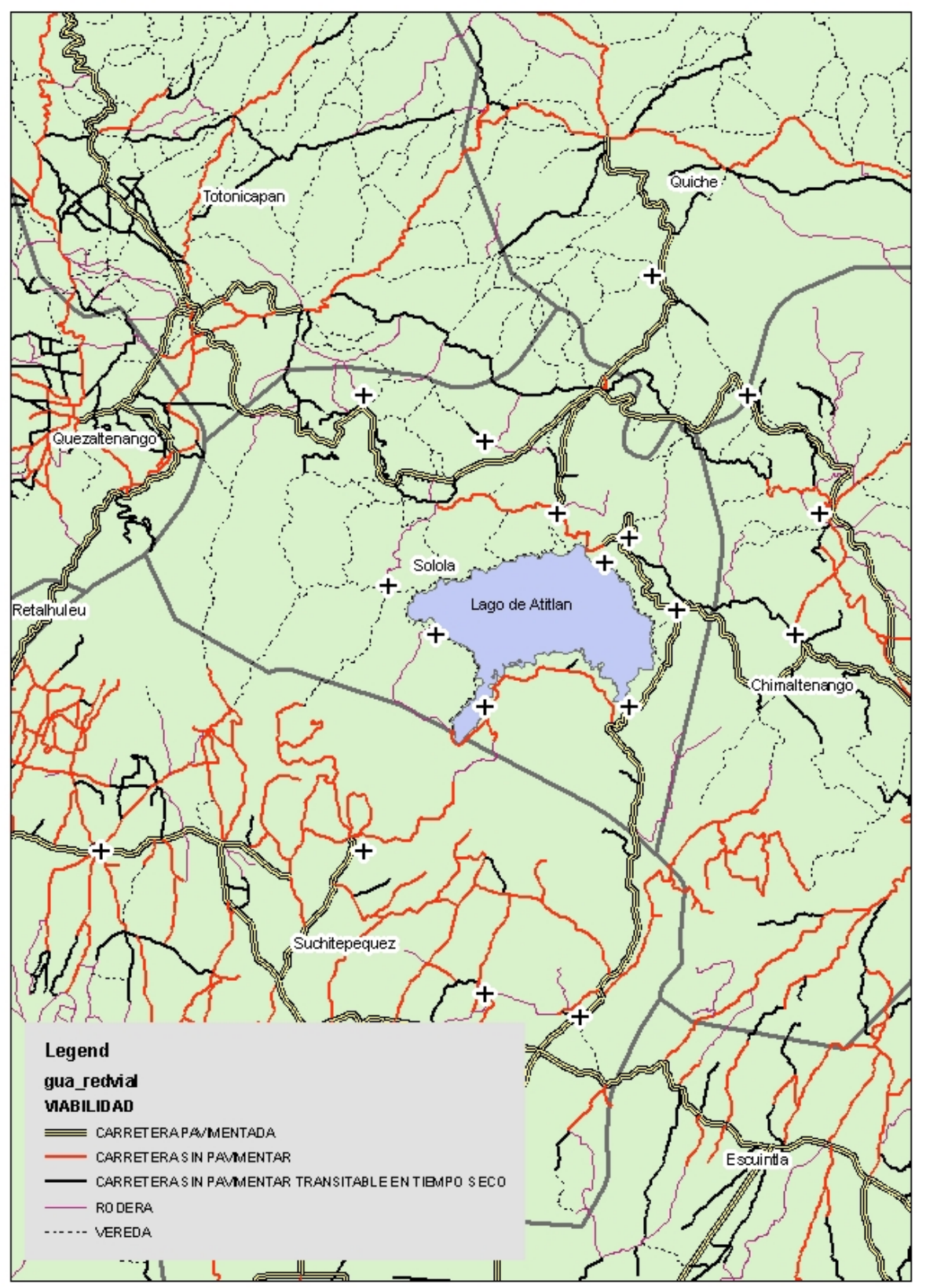

Figure 4: Road network in study area. 


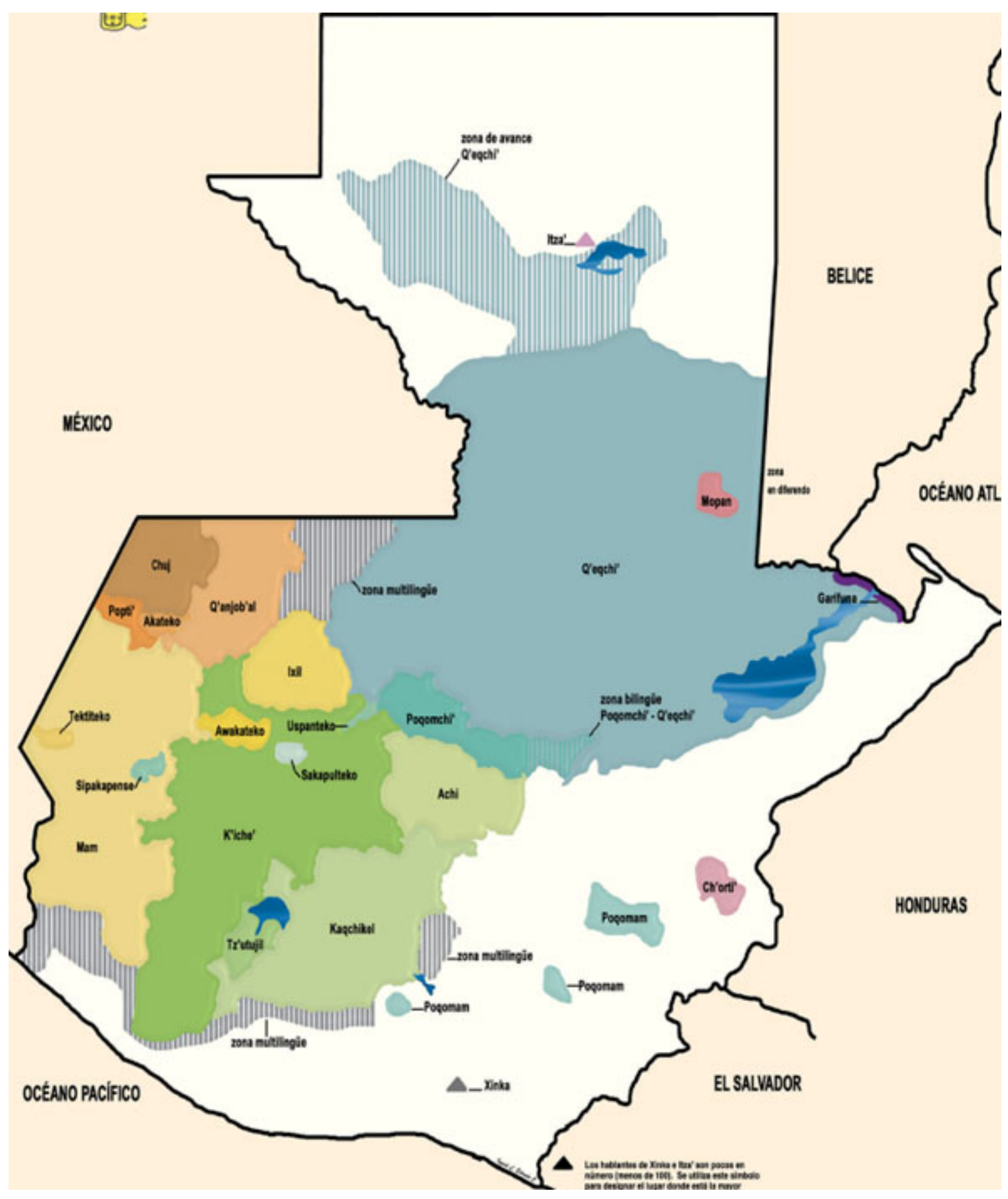

Figure 5: Language areas of Guatemala (Spanish area is white). (copied without permission from Richards 2003). 


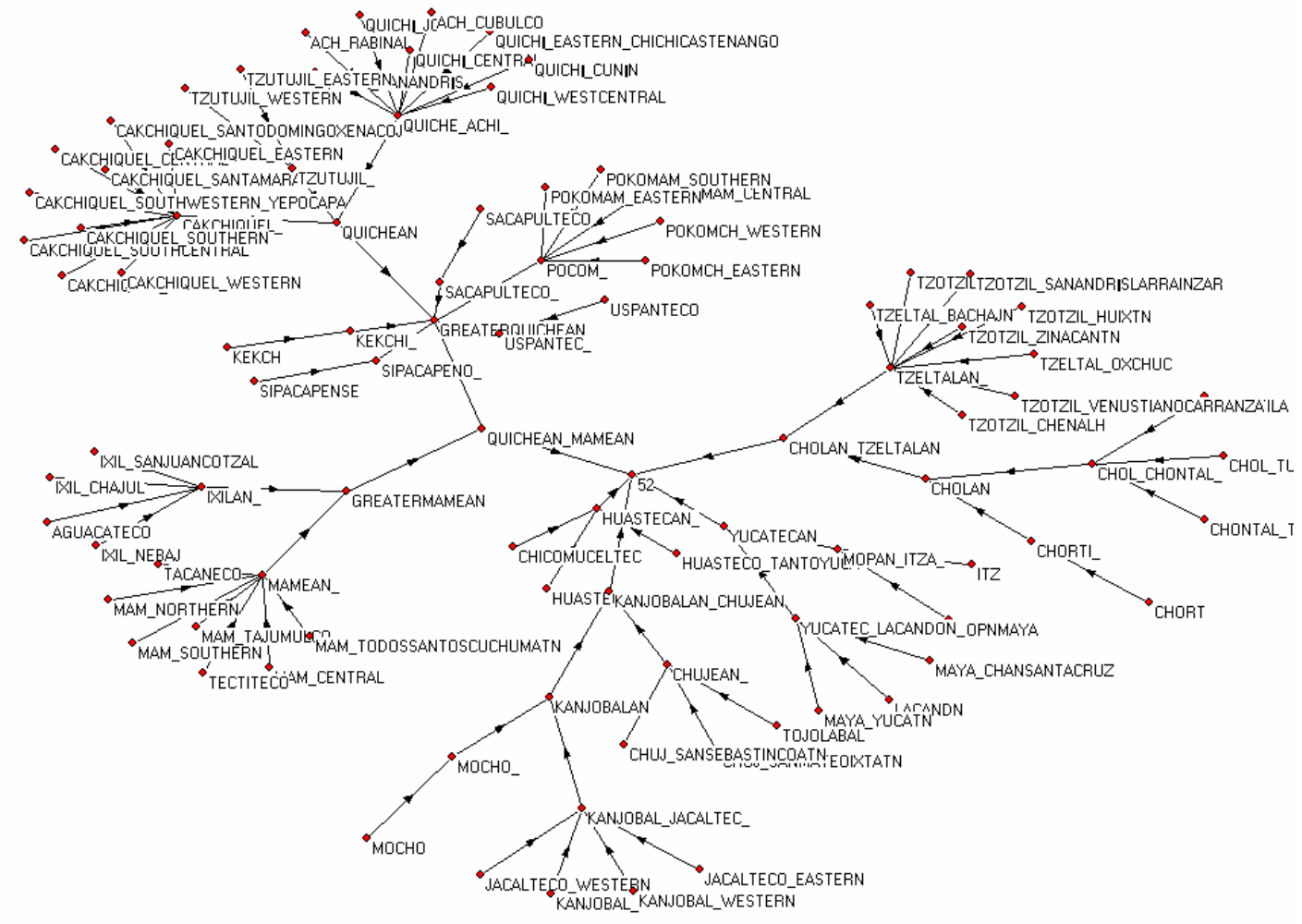

Figure 6: Graph depicting Mayan language phylogeny. The node labeled " 52 " is the parent language for all Maya languages. 